\title{
DESAFIOS PERCEBIDOS POR ALUNOS SURDOS NO ENSINO DA DISCIPLINA DE CONTABILIDADE INTRODUTÓRIA NOS CURSOS DE CIÊNCIAS CONTÁBEIS E ADMINISTRAÇÃO
}

Bianca Ribeiro Lages Santos 1

Flaviano Costa ${ }^{2}$

- Artigo recebido em: 08/05/2018 -- Artigo aceito em: 23/01/2020 •-. Segunda versão aceita em: 22/02/2020

\section{RESUMO}

Este estudo se propõe a investigar quais são os desafios percebidos pelos alunos surdos no ensino da disciplina de Contabilidade Introdutória nos cursos de Contabilidade e Administração. Trata-se de uma pesquisa qualitativa, que utilizou de entrevistas semiestruturadas com os dados examinados pela técnica de análise de conteúdo. Foi realizada entre março/2017 e março/2018, tendo como sujeitos alunos surdos. Está fundamentada na teoria histórico-cutural, nos pressupostos de Vigotsky (1989, 1991 e 1997). Como exemplos dos desafios identificados tem-se: [1] a barreira da linguagem; [2] a falta de conhecimento e de sensibilidade em relação à surdez; [3] a resistência com relação às adaptações possíveis de estratégias de ensino, de materiais e de utilização de recursos que facilitam a aprendizagem para alunos surdos; [4] a falta de sinais para representar os termos técnicos. Como contribuição traz sugestões para uma melhora no ensino de contabilidade nessa perspectiva da inclusão de surdos no ensino regular.

Palavras-Chave: Ensino de Contabilidade Introdutória. Inclusão de alunos surdos. Teoria Histórico-cutural.

\section{CHALLENGES PERCEIVED BY DEAF STUDENTS IN THE TEACHING OF THE INTRODUCTORY ACCOUNTING DISCIPLINE IN ACCOUNTING SCIENCES AND ADMINISTRATION COURSES}

\begin{abstract}
This study aims to investigate the challenges perceived by deaf students in the teaching of Introductory Accounting in Accounting and Administration courses. This is a qualitative research, which used semi-structured interviews with the data

\footnotetext{
1 Mestra em Contabilidade pela Universidade Federal do Paraná (UFPR). Professora do Departamento de Gestão e Negócios (DGN) do Instituto Federal do Piauí (IFPI). Endereço: Rua Álvaro Mendes, 94 - Centro (Sul), Prédio B, Departamento de Gestão e Negócios, Teresina PI, 64001-270. E-mail: bialages@ifpi.edu.br/ bialages@yahoo.com.br. Telefone: (86) 3131-9410

2 Doutor em Contabilidade e Controladoria pela FEA/USP. Professor do Departamento de Ciências Contábeis da UFPR. Endereço: Rua Prefeito Lothário Meissner, 632 - Jardim Botânico - Setor de Ciências Sociais Aplicadas, Curitiba - PR, CEP 80.210-170. E-mail: flaviano.ufpr@gmail.com. Telefone: (41) 3360-4404.
}

https://orcid.org/0000-0002-4694-618X.
\end{abstract}


Desafios Percebidos por Alunos Surdos no Ensino da Disciplina de Contabilidade Introdutória nos Cursos de Ciências Contábeis e Administração

examined by the technique of content analysis. It was carried out between March / 2017 and March / 2018, having deaf students as subjects. It is based on the historical-cultural theory, in the assumptions of Vigotsky (1989, 1991 and 1997). Examples of the identified challenges are: [1] the language barrier; [2] the lack of knowledge and sensitivity regarding deafness; [3] resistance to possible adaptations of teaching strategies, materials and resource utilization that facilitate learning for deaf students; [4] lack of signals to represent technical terms. As a contribution brings suggestions for an improvement in accounting education in this perspective of the inclusion of deaf people in regular education.

Keywords: Introductory Accounting Teaching. Inclusion of deaf students. Historicalcultural theory.

\section{INTRODUÇÃO}

A Contabilidade surgiu com a civilização e não deixará de existir em função dela (Sá, 1997). A necessidade da humanidade de verificar e controlar seu patrimônio deu origem à Contabilidade que por sua vez tem a finalidade de gerar informações para registro e auxílio em decisões a respeito do mesmo (Zanluca \& Zanluca, 2006). Seguindo esse pensamento, Peleias, Silva, Segreti e Chirotto (2007) afirmam que o desenvolvimento da ciência contábil acompanha as mudanças da sociedade em que se apresenta.

Nesse contexto, a educação, também é um processo que passa por constantes adaptações devido à geração de novos conhecimentos e às mudanças na sociedade. O Brasil, como outros países, enfrenta o grande desafio da inclusão de alunos público-alvo da educação especial (PAEE) em turmas regulares, como mencionam Duarte, Rafael, Filgueiras, Neves e Ferreira (2013), fazendo referência às deficiências. Esse movimento vinha acontecendo no ensino infantil, fundamental e médio e recentemente no ensino técnico e superior.

De acordo com a Resolução $n^{\circ}$ 04, do Conselho Nacional de Educação (CNE), de 10/2009, que institui as Diretrizes Operacionais para o Atendimento Educacional Especializado - AEE na Educação Básica, o público-alvo da educação especial inclui alunos com deficiência, transtornos globais do desenvolvimento e altas habilidades/superdotação. A mesma resolução define deficiência como impedimentos de longo prazo de natureza física, intelectual, mental ou sensorial.

Importante frisar que o tema inclusão de alunos PAEE vem despertando interesse e sendo estudado por pesquisadores de diversas áreas, principalmente da área da educação e da psicologia, em âmbito nacional e internacional. Como exemplo, tem-se Cawthon (2001); Lang (2002); Jambor (2005); Lacerda (2006); Cruz e Dias (2009); Pieczkowski (2012); Vermeulen, Denessen e Knoors (2012); Gonçalves e Festa (2013); Lacerda, Albres e Drago (2013); Marschark, Morrison, Lukomski, Borgna e Convertino (2013); Antunes, Faria, Rodrigues e Almeida (2013); Duarte et al (2013); Moriña, Cortés-Vega e Molina (2015); Witt, Alias, Ibrahim, Shing e Mohd.Rashid (2015); Marschark, Shaver, Nagle e Newman (2015); Spencer, Marschark, Machmer, Durkin, Borgna e Convertino (2018); Hammami, Saeed, Mathkour e Arafah (2019). A preocupação desses estudos vai além da simples inserção desse público em turmas com alunos sem necessidades 
educativas especiais, abrangendo a permanência e formação dos citados alunos.

Adicione-se a essa discussão, a publicação no Portal Brasil (2012), que fez referência a um aumento de $933,6 \%$ na quantidade de matrículas de pessoas com deficiência na educação superior no período compreendido entre 2000 e 2010. Em 2012 havia 22.455 matrículas de alunos com deficiência no ensino superior, dos quais 16.790 em instituições privadas e 4.437 em instituições federais, como consta no estudo de Duarte et al (2013).

Uma importante conquista foi a Lei Brasileira de Inclusão da Pessoa com Deficiência (Lei 13.146/2015) que assegura a oferta de um sistema educacional inclusivo em todos os níveis e modalidades e determina que as instituições de ensino elaborem um projeto pedagógico institucionalizando o atendimento educacional especializado com profissionais de várias áreas, sem nenhum custo para o aluno. Entre outras garantias está a oferta de educação bilíngue em escolas inclusivas e oferta de ensino da Linguagem Brasileira de Sinais (Libras) para ampliar as habilidades funcionais do estudante surdo, de forma a promover a sua autonomia e participação.

Parte do PAEE é composto por pessoas com limitações auditivas, que segundo o último censo correspondem a 5,1\% da população total (IBGE, 2010). Dispositivos legais específicos, como a Lei de Inclusão da Pessoa com Deficiência, asseguram o direito à educação para alunos surdos, mas é importante verificar se esse direito está sendo atendido de forma satisfatória e como está ocorrendo o ensino a esse público.

Nesse contexto do ensino de Contabilidade, moldando-se ao cenário em transformação e da inclusão de alunos surdos na educação regular, este estudo investiga como está ocorrendo o ensino de contabilidade para alunos surdos, orientado pela seguinte questão de pesquisa: Quais são os desafios percebidos pelos alunos surdos no ensino da disciplina de Contabilidade Introdutória nos cursos de Contabilidade e Administração? Para responder tal questão o objetivo principal deste trabalho consiste em investigar quais são os desafios percebidos pelos alunos surdos no ensino da disciplina de Contabilidade Introdutória nos cursos de Contabilidade e Administração. A justificativa de escolha desses dois cursos ocorreu pela acessibilidade e disponibilidade dos alunos foco da pesquisa, visto que, nos últimos anos observou-se, em algumas instituições de ensino superior, aumento de ingressantes surdos ou com deficiência auditiva nesses dois cursos de graduação, fato esse que possibilitou a seleção dos respondentes investigados na presente pesquisa. E o estudo enfocou a disciplina Contabilidade Introdutória, por ela fazer parte dos conteúdos curriculares dos cursos de Administração e Ciências Contábeis (Brasil/MEC/CNE n 10/2004; Brasil/MEC/CNE $\left.n^{\circ} 4 / 2005\right)$.

A justificativa para a realização da pesquisa é em função da importância de se compreender mais a respeito do ensino de Contabilidade para estudantes surdos, de forma a garantir uma melhor aprendizagem para os estudantes com essa especificidade. Os estudos anteriormente mencionados pesquisaram a inclusão de forma ampla, abrangendo todas as necessidades especiais e o ensino superior como um todo. Esse estudo limita-se a especificidade da surdez, em um componente curricular que aborda conhecimentos necessários ao funcionamento das empresas, comum a dois cursos da área de gestão e 
Desafios Percebidos por Alunos Surdos no Ensino da Disciplina de Contabilidade Introdutória nos Cursos de Ciências Contábeis e Administração

negócios, entre os mais ofertados e procurados no país, segundo o MEC/INEP (2019). Para tanto, a identificação dos desafios e a formulação de um diagnóstico permite identificar as ações a serem tomadas e investimentos a serem feitos para facilitar a inclusão do aluno surdo e melhorar as abordagens práticas de ensino contábil.

Nesse sentido, o crescimento no número de matrículas de alunos surdos no Ensino Superior acende uma luz de alerta para a importância do estudo do fenômeno da inclusão de alunos com essa característica. Uma vez que não basta inseri-los no Ensino Superior, mas há de se garantir a sua permanência e a sua conclusão com eficiência. Para isso, devem-se desenvolver estudos que propiciem a discussão não só da inclusão como o acesso do aluno ao contexto acadêmico, mas das necessidades específicas para o seu ensino e sua formação. Caso contrário, o aluno desistirá ou saíra com uma formação medíocre. Portanto, esse estudo pode trazer elementos reflexivos para a inclusão, manutenção e formação do aluno surdo nas áreas de Administração e Ciências Contábeis que carecem de pesquisas sobre essa temática.

\section{PLATAFORMA TEÓRICA}

Para dar suporte ao desenvolvimento da pesquisa, aborda-se os temas principais: o ensino de Contabilidade no Brasil; acesso do aluno surdo ao ensino acadêmico, finalizando com a aplicação da Teoria Histórico-Cultural ao ensino de Contabilidade para alunos surdos.

\subsection{Acesso do Aluno Surdo ao Ensino Acadêmico}

Os aspectos relacionados à educação de pessoas surdas são vários e embora cada experiência com a surdez seja única, pois cada ser é singular, com suas características biológicas e sua personalidade, está inserida em um contexto sociocultural, podendo este ser totalmente diferente dos demais ou não (Fernandes, 2011 ). Complementarmente, Cruz e Dias (2009) ponderam que sob o ponto de vista sócio-antropológico, os surdos possuem diferenças linguísticas e culturais, mas, na maioria das vezes frequentam uma escola padronizada e organizada para alunos ouvintes. Com esse pensamento, tentou-se colocar aqui alguns aspectos considerados importantes e presentes em grande parte dessas vivências.

Para o MEC/SEESP (2006, p. 19) a surdez é a "privação sensorial que interfere diretamente na comunicação, alterando a qualidade da relação que o indivíduo estabelece com o meio [...]". O Decreto n 5.296/04 da Presidência da República, em seu art. $5^{\circ} \S 1^{\circ}$ alínea b, define deficiência auditiva como: "perda bilateral, parcial ou total, de quarenta e um decibéis $(\mathrm{dB})$ ou mais, aferida por audiograma nas frequências de $500 \mathrm{~Hz}, 1.000 \mathrm{~Hz}, 2.000 \mathrm{~Hz}$ e $3.000 \mathrm{~Hz}$ " (Brasil, 2004). Com base nessas definições, a deficiência auditiva é colocada como uma redução da capacidade de ouvir sons, prejudicando o indivíduo no seu desenvolvimento educacional, na aquisição da linguagem oral e na interação com o meio, na qual grande parte da transmissão de informações ocorre por meio do canal auditivo.

É comum o pensamento equivocado de que os surdos têm todas as formas de linguagem prejudicadas. A linguagem não existe somente na forma oral, há 
também a comunicação simbólica que acontece por meio de signos que representam a realidade, e se concretiza por meio de desenhos, gestos, escrita, sons, ícones, cores e no caso dos surdos, sinais. Desta forma, a surdez prejudica principalmente o desenvolvimento da linguagem oral, permanecendo o potencial e a oportunidade das demais formas de comunicação (Fernandes, $2011)$.

Com relação à modalidade de ensino para surdos, no transcorrer da história, surgiram algumas correntes filosóficas utilizadas como modo de ensino para surdos: [1] o Oralismo, que prega a reabilitação, com estímulos auditivos, em busca da "normalidade" (Goldfeld, 2002), esperada pela sociedade; [2] a Comunicação Total, que surgiu como uma tentativa de superar o fracasso do método oral como única forma de linguagem no processo da educação, pregando a utilização de todas as formas possíveis de se comunicar e pecando, segundo Doziat (1999) em não priorizar o desenvolvimento cognitivo dos surdos, com a aquisição da língua de sinais como primeira língua, fato essencial para toda aprendizagem futura; e [3] o Bilinguismo, que surgiu na década de 90 do século passado e leva a uma concepção da pessoa surda como um estrangeiro, uma vez que concebe a língua de sinais como a língua natural da pessoa surda e que esta faz parte, como coloca Fernandes (2008), de uma minoria linguística.

A Libras (Língua Brasileira de Sinais) tem sua origem na Língua de Sinais Francesa. Diferentemente das línguas orais-auditivas, ela efetua-se no campo visual e utiliza-se de elementos corporais e faciais, organizados em movimentos no espaço para constituir os sinais (unidades de sentido). E esses não se restringem a um sistema de gestos naturais ou mímicos, eles podem representar qualquer dado da realidade social (Fernandes, 2011).

Dos anos 90 para os dias atuais, as políticas educacionais de inclusão escolar vêm fazendo com que aumente a presença de alunos público alvo da educação especial no ensino superior no país. Ansay (2010) registra que entre 2003 e 2005 o número de matrículas de alunos com necessidades educacionais especiais no ensino superior cresceu de 5.078 para 11.999, representando um crescimento de 136\%. O número de alunos surdos era em 2003, 665; em 2004, 974, chegando a 2.428 em 2005, representando um aumento de $265 \%$ entre 2003 e 2005. Em 2009 foram registradas 20.019 matrículas de alunos com deficiência no ensino superior. Dentre elas, $22 \%$ correspondiam aos portadores de deficiência auditiva, $9 \%$ aos denominados com surdez e 1\% aos com surdo-cegueira (MEC/INEP, 2010). Esse crescimento representativo no número de matrículas de alunos surdos justifica-se por que, além das já mencionadas políticas educacionais de inclusão, também o aumento da oferta do ensino à distância e a criação, em 2006, do curso de licenciatura em Letras/Libras, oferecido principalmente nas universidades federais do país e em algumas faculdades particulares ocorreram.

No Brasil, vários dispositivos asseguram o acesso e a permanência dos alunos surdos no Ensino Superior. Desde a Constituição Federal de 1988 até a Lei $n^{\circ} 13.146$ de 6 de julho de 2015 (Lei Brasileira de Inclusão da Pessoa com Deficiência) alguns dispositivos vieram construindo o histórico de legislações das conquistas do povo surdo, tanto no plano social como educacional.

Alguns estudos foram feitos abordando a inclusão de alunos surdos e o seu desempenho. A maioria deles é no ensino fundamental e no ensino médio. Como 
Desafios Percebidos por Alunos Surdos no Ensino da Disciplina de Contabilidade Introdutória nos Cursos de Ciências Contábeis e Administração

exemplo, o estudo de Lacerda (2006), aborda uma experiência de inclusão de aluno surdo em uma escola regular. Entrevistou professores, intérpretes, alunos surdos e alunos ouvintes. A análise dos depoimentos indicou problemas como: o desconhecimento sobre a surdez e suas implicações educacionais; dificuldades existentes na interação professor/intérprete; a incerteza a respeito dos papeis dos integrantes do processo de ensino; dificuldade com adaptações curriculares e estratégias de aula e exclusão de alunos surdos de atividades. A autora coloca que estudos no Brasil e no exterior apontam que existe um descompasso na competência para aspectos acadêmicos entre os estudantes surdos e os ouvintes, apesar de possuírem semelhantes capacidades cognitivas.

Complementarmente, a autora argumenta que ocorreram várias formas de inclusão e que "a maioria dos alunos surdos sofreu uma escolarização pouco responsável" (p. 2) e indica a necessidade de se pensar em um modelo novo de escola, sem forçar a inserção do aluno surdo em modelo concebido para semelhança e não para acolher as diferenças. Outro estudo realizado com aproximadamente 500 estudantes secundários de escolas regulares nos Estados Unidos da América - EUA examinou a importância relativa de algumas características individuais, de ambiente familiar, de comunicação e educacionais para o desempenho acadêmico de estudantes surdos e com deficiência auditiva. Constataram que o desempenho acadêmico desses estudantes está relacionado com um conjunto complexo de fatores ligados aos próprios alunos, seus familiares e suas experiências durante a vida escolar (Marschark et al, 2015).

Há uma percepção no crescimento do interesse, por parte dos pesquisadores, a respeito da inclusão no ensino superior. Como exemplo, Sládek, Bednárová e Milér (2011) constataram que os cursos universitários padrão não consideram as limitações de alguns estudantes, sendo elaborados para alunos semelhantes sem ponderar as diferenças entre eles. Nesses cursos, são exigidos dos alunos todos os sentidos com o objetivo de garantir a transmissão de informação e aquisição de competências. Na existência de estudantes com alguma limitação, o processo de ensino e aprendizagem não se mostra eficiente, sendo necessária a busca pelo conhecimento sobre as desvantagens específicas dos discentes que influenciam no processo de ensino e aprendizagem e a procura por métodos adicionais que ajudem no processo. Daroque e Padilha (2015) procurando ampliar as fontes de informação para o estudo na área de educação de surdos, com base na perspectiva histórico-cultural, entrevistaram quatro alunos surdos e quatro docentes de duas IES de um município da Grande São Paulo. Chegaram à conclusão que:

[...] para os surdos cursarem o Ensino Superior, é necessário pensar nas condições de sua escolarização na Educação Básica, pois esses alunos carregaram durante anos uma defasagem quanto à elaboração de conhecimentos por conta do desenvolvimento insuficiente de uma língua de reflexão. Faltam-lhes conteúdos prévios importantes por conta de obstáculos para a comunicação eficaz em língua de sinais e há o desconhecimento de instituições de ensino e de profissionais quantos às especificidades de sua educação (p. 115). 
Complementarmente, as autoras, com base nos depoimentos, refletem que: só a presença do intérprete de língua de sinais em sala de aula não é suficiente para resolver todos os problemas que envolvem a inclusão do aluno surdo na instituição de ensino. E afirmam ser necessário, na atual fase transitória de implantação das garantias legais, "oportunizar aos alunos surdos universitários, em contra turno, o ensino de Língua Portuguesa instrumental como segunda língua, pois, para eles, é indispensável à capacitação para a leitura e escrita" (p. $117)$.

\subsection{Aplicação da Teoria Histórico-Cultural ao Estudo do Ensino de Contabilidade para Alunos Surdos}

A teoria histórico-cultural (sociocultural, sócio histórica ou sócio interacionista, como também é conhecida) desenvolvida por Lev Semenovich Vygotsky $(1896 ; 1934)$ explica a aquisição do conhecimento humano a partir do contexto do indivíduo e, portanto, da sua história. Vygotsky defendia que é nas interações estabelecidas entre o homem e o meio que as funções psíquicas, especificamente humanas, nascem e se desenvolvem (Rego, 2013).

Na perspectiva de Vygotsky e de seus seguidores, os processos psicológicos superiores (que são necessários à construção do conhecimento e que, em retorno, são influenciados por este) ocorrem com a interação social entre pessoas com níveis diversos de desenvolvimento, compartilhando vivências e mediada por instrumentos ou signos que permitem ou facilitam a internalização de experiências e informações fornecidas pela cultura em que estão imersas e que se formou ao longo da história. O indivíduo deve ser estudado dialeticamente, considerando a sua evolução biológica e o seu desenvolvimento sócio histórico.

A interação social propicia a transmissão e troca de conhecimentos entre pessoas com nível de capacidade diferente, o que retoma o conceito da zona de desenvolvimento potencial dos alunos. Para Vygotsky (1991), o ensino deve partir da base que o aluno já tem (do que ele já sabe, conhecimento que ele já absorveu, da sua observação do mundo, do que consegue realizar sozinho) e ser capaz de ampliar e desafiar a construção de novos conhecimentos por meio do outro (professor ou colega). Lantolf e Poehner (2014) argumentam que a atividade cooperada desenvolvida durante essas interações desempenha dupla função, promove o desenvolvimento do aluno e fornece insights sobre habilidades que ainda não emergiram completamente, mas estão em processo de formação.

Seguindo essa linha de raciocínio, a instituição de ensino tem o papel de propiciar as condições adequadas para que todos os alunos tenham acesso às informações e experiências e de modo a alcançar um aprendizado eficiente (Rego, 2013). Isso, com relação ao aluno surdo, inclui ações fomentadoras da inclusão, discussão do tema, de planejamento da atividade de ensino voltada para a surdez, entre outras.

Os mediadores têm a função de orientar os alunos a novas formas de pensar e agir (Poehner \& Infante, 2017). O professor e o intérprete, uma vez que possibilitam a transmissão e a troca de conhecimentos, são mediadores das interações que ocorrem em sala de aula e, portanto, devem ter o seu papel estudado e definido. 
Desafios Percebidos por Alunos Surdos no Ensino da Disciplina de Contabilidade Introdutória nos Cursos de Ciências Contábeis e Administração

A perspectiva histórica e cultural é necessária para o estudo do desenvolvimento das funções psicológicas superiores. Para Daniels (2016) a abordagem de Vygotsky tenta teorizar e fornecer ferramentas metodológicas para investigar os processos pelos quais fatores sociais, culturais e históricos moldam o funcionamento humano. Assim é importante a abordagem da vida estudantil anterior do aluno surdo, de suas vivências, das culturas a que tem acesso (surda e ouvinte), da visão social de sua especificidade. Verificando como esses aspectos influenciam no seu desenvolvimento.

Para Vygotsky, as ferramentas psicológicas são dispositivos para dominar os processos mentais. A linguagem, os sistemas de símbolos algébricos, os esquemas, os mapas, todos os tipos de sinais convencionais, entre outros são exemplos de ferramenta psicológicas. Elas são criadas artificialmente e tem origem social (Minick, 1987). Lantolf e Poehner asseveram que as percepções de mundo de um indivíduo são moldadas pelas categorias que lhes são disponibilizadas à medida que se apropria de sua linguagem e, consequentemente, desenvolve sua mente. Nesse sentido, é de grande importância a questão da mediação, por meio de instrumentos e signos, presente na atividade do ensino de Contabilidade Introdutória para alunos surdos, visto que se presume um papel fundamental da linguagem, das estratégias de ensino e dos recursos didáticos utilizados, devido à especificidade do tipo do aluno em questão.

Embora seja dado um grande foco à base social com sua carga histórica e cultural, a teoria também concebe a base biológica como formadora do ser humano, assim informações como a origem e o grau da surdez devem ser consideradas no estudo.

Desta forma, a teoria histórico-cultural de Vygotsky se mostra adequada e atual para embasar pesquisas em educação. Soma-se o fato de que ele foi "o primeiro pensador cujas ideias abordaram conceitos centrais do projeto de inclusão escolar" (Beyer, 2005, p. 1). Em seu trabalho Obras Escogidas, Volume V, Fundamentos de defectologia (1997) ele faz uma defesa a não segregação escolar de alunos com deficiência.

Nessa obra Vygotsky (1997) expõe que o ser humano não é só biológico, com suas características físicas, más é constituído também do meio social que o orienta e o modifica. O homem não tem uma comunicação pura, associal e direta com o mundo. E a falta de um dos sentidos como a visão ou a audição prejudica as funções sociais, degenera os laços sociais e modifica o sistema de condução das informações (Vygotsky, 1997).

Nesse contexto, torna-se essencial o conhecimento sobre as características específicas, história e cultura do aluno surdo para que o processo de ensino ocorra de forma eficiente. Respeitando suas especificidades e adequando estratégias, posturas, currículo e utilizando ferramentas que possam ajudar no desenvolvimento do aluno.

\section{METODOLOGIA}

Visando responder à questão de pesquisa e alcançar o objetivo estipulado, o trabalho consistiu em uma pesquisa qualitativa de nível exploratório (Martins \& Theóphilo, 2007). De acordo com Gil (2008), a finalidade da pesquisa exploratória é o desenvolvimento, o esclarecimento e a modificação de conceitos e ideias. $E$ 
acrescenta que esse tipo de estudo é indicado para temas pouco explorados, sobre os quais é difícil a formulação de hipóteses precisas e operacionalizáveis.

Uma abordagem dialética também se fez presente no estudo. Prodanov e Freitas (2013) argumentam que o método dialético se faz por meio da interpretação vinculante da realidade como um todo, considerando que: "os fatos não podem ser relevados fora de um contesto social, político, econômico etc. [...] As coisas e os acontecimentos existem como um todo, ligados entre si, dependentes uns dos outros" (p. 34). A pesquisa apresentou como característica do método, o estudo do fenômeno contemporâneo (a inclusão de alunos surdos no ensino de Contabilidade Introdutória) em vários aspectos, relações e conexões, considerando o contexto histórico e cultural.

A pesquisa utilizou a estratégia levantamento que, de acordo com Martins e Theóphilo (2007), é aplicado a estudos de fenômenos que ocorrem naturalmente e que possuem uma multiplicidade de influências que podem interferir nos processos estudados, sendo uma estratégia apropriada para a análise de fatos e descrições. Os trabalhos que analisam conjuntamente dados pessoais, comportamento, o ambiente dos respondentes, somando-se a dados sobre nível de informações, opiniões, atitudes, mensurações e expectativas são mais produtivos do que os que abordam apenas um desses aspectos (Martins \& Theóphilo, 2007). Os autores verificaram que as pesquisas de levantamento não se restringem a estudos de relato de distribuições e relações, podendo alcançar também sua explicação e interpretação.

Foi realizado um levantamento das instituições que tem ou já tiveram alunos surdos, nos cursos técnicos e de graduação, de Contabilidade e de Administração, por meio de e-mail, no qual se explicava um pouco sobre a pesquisa, enviado aos coordenadores dos cursos de contabilidade e administração no Brasil (em um número de 1.476 coordenações), com base nos endereços eletrônicos fornecidos pelo MEC, por meio do Sistema Eletrônico de Serviço de Informação ao Cidadão (e-SIC). 15 IES no sul e sudeste responderam ter alunos surdos; 25 IES, em todas as regiões, asseguraram já terem tido alunos surdos; e 14, em todas as regiões, afirmaram ter ou já ter tido alunos parcialmente surdos. Em seguida, para as instituições que afirmaram ter tido a experiência de inclusão com aluno surdo, foram enviados e-mails com convite a participar da pesquisa por meio de entrevista online a ser gravada e transcrita, com alunos surdos (população da pesquisa), aos cuidados dos coordenadores, com objetivo de investigar o processo de ensino da disciplina Contabilidade Introdutória a esses alunos.

A escolha pela entrevista online se deu pela população, que embora tenha se mostrado de tamanho pequeno, se encontre espalhada em pontos distantes territorialmente no país. Nos casos possíveis foram feitas entrevistas pessoalmente.

A pesquisa foi aprovada por um Comitê de Ética em Pesquisa. As entrevistas e análise de seu conteúdo foram autorizadas por meio de Termo de consentimento Livre e Esclarecido. Devido às transcrições terem se constituído em longos textos e respeitando as características do aluno surdo, não foi solicitado a validação por parte destes, isso representando uma limitação da pesquisa.

Foi construído um roteiro para a entrevista, e as questões foram distribuídas em blocos e em categorias para guiar a análise dos dados obtidos. A

26 Revista Contabilidade Vista \& Revista, ISSN 0103-734X, Universidade Federal de Minas Gerais, Belo Horizonte, v. 30, n. 3, p. 18-45, set./dez. 2019 
Desafios Percebidos por Alunos Surdos no Ensino da Disciplina de Contabilidade Introdutória nos Cursos de Ciências Contábeis e Administração

predominância foi de questões abertas. As perguntas visavam identificar os desafios percebidos pelos alunos surdos no ensino da disciplina de Contabilidade Introdutória nos cursos de Contabilidade e Administração. Os blocos abordam as percepções dos participantes em relação ao processo do ensino de Contabilidade Introdutória para o aluno surdo, os aspectos que mais influenciam o fenômeno em estudo, a caracterização dos participantes e a história e a cultura do aluno surdo. Os roteiros das entrevistas foram construídos com base nos objetivos da pesquisa e na plataforma teórica levantada.

Para a análise das entrevistas, os participantes foram codificados para a não identificação dos mesmos. Passaram a ser tratados como: Alunos - A. Numerados seguindo a organização dada às instituições, iniciando com a que apresenta maior número de participantes até aquela com uma quantidade menor de indivíduos entrevistados. As informações verificadas foram organizadas em categorias, para facilitar a análise.

Os dados coletados com os depoimentos das entrevistas foram tratadas com a técnica de Análise de Conteúdo. Para Martins e Theóphilo (2007) a Análise de Conteúdo é uma técnica de estudo objetiva e sistemática, no qual "O interesse não se restringe à descrição dos conteúdos. Deseja-se inferir sobre o todo da comunicação. Entre a descrição e a interpretação interpõe-se a inferência" (p. 95-96).

Os áudios das entrevistas foram transcritos para análise com base no contexto histórico-cultural, que buscou identificar os desafios percebidos pelos alunos surdos no ensino da disciplina de Contabilidade Introdutória nos cursos de Contabilidade e Administração.

Indica-se que em quatro entrevistas com alunos não foi possível a presença do intérprete que o acompanha na instituição de ensino, tendo sido duas delas auxiliada por algum familiar com conhecimento em Libras. Duas alunas fizeram leitura labial, respondendo de forma oral, sendo constatada uma dificuldade de compreensão das perguntas, que foram refeitas várias vezes, e de forma diferente, até o seu entendimento. Todos os participantes autorizaram o uso das entrevistas na pesquisa por meio de Termo de Consentimento Livre e Esclarecido.

\section{RESULTADOS E DISCUSSÃO DOS DADOS}

Nesta seção busca-se analisar os dados coletados por meio da realização de entrevistas, com o objetivo de responder à questão de pesquisa. A subseção 4.2 expõe e examina os achados, averiguando os dados por categorias, tentando deixar bem evidente a percepção do aluno.

\subsection{Caracterização da Amostra}

A amostra foi composta de 9 alunos surdos apresentados na Figura 1. 


\begin{tabular}{|c|c|c|c|c|}
\hline Instituição & $\begin{array}{c}\text { Categoria } \\
\text { Administrativa }\end{array}$ & $\begin{array}{c}\text { Unidade da } \\
\text { Federação }\end{array}$ & $\begin{array}{c}\text { Alunos Surdos } \\
\text { Participantes }\end{array}$ & $\begin{array}{c}\text { Modalidade do } \\
\text { Curso }\end{array}$ \\
\hline Inst. 1 & $\begin{array}{c}\text { Pública } \\
\text { Federal }\end{array}$ & PI & 3 (A); A2 e A3) & Técnico \\
\hline Inst. 2 & $\begin{array}{c}\text { Pública } \\
\text { Federal }\end{array}$ & RS & 2 (A4; A5) & Superior \\
\hline Inst. 3 & $\begin{array}{c}\text { Privada } \\
\text { (Comunitária) }\end{array}$ & SC & 1 (A6) & Superior \\
\hline Inst. 4 & $\begin{array}{c}\text { Privada com } \\
\text { fins lucrativos }\end{array}$ & PR & 1 (A7) & Superior \\
\hline Inst. 5 & $\begin{array}{c}\text { Pública } \\
\text { Federal }\end{array}$ & PR & 1 (A8) & Técnico \\
\hline Inst. 6 & $\begin{array}{c}\text { Privada sem } \\
\text { fins lucrativos }\end{array}$ & SP & 1 (A9) & Superior \\
\hline
\end{tabular}

Figura 1 - Codificação das Instituições e Alunos Surdos

Fonte: Elaborado pelos autores.

\subsubsection{Perfil dos Respondentes}

Três alunos estão cursando e uma já concluiu o Curso Superior de Ciências Contábeis; uma estuda o curso Superior de Administração, dois o Curso Técnico de Contabilidade e dois o Técnico de Administração. Eles têm a média de 23 anos de idade. Cinco se declararam oralizados e quatro deles têm muita dificuldade com a língua oral. Mais da metade deles são surdos de nascença. Dois alegam não saber a causa dessa deficiência sensorial, os demais apontaram doenças, como a rubéola ou meningite, adquirida na gestação da mãe ou na primeira infância, reação a alguma medicação forte ingerida ou à genética. Todos demonstram fazer leitura labial, uns com mais dificuldade que os outros.

\subsection{Apresentação e Análise dos Resultados}

A percepção sobre os desafios no ensino da disciplina de Contabilidade Introdutória para alunos surdos foi coletada por meio de entrevista contendo 49 perguntas, organizadas nos blocos: Identificação das Percepções (dividido em oito categorias); Identificação do Participante e História e Cultura. Essa organização dos roteiros das entrevistas teve o intuito de facilitar a explanação dos achados, expostos a seguir, de acordo com cada categoria.

\subsubsection{Categoria Preparo para Inclusão}

As perguntas presentes nessa categoria visavam identificar o preparo dos alunos surdos entrevistados com relação ao processo de ensino-aprendizagem de Contabilidade Introdutória. Assim, foi verificado que para a maioria, o início do curso foi muito difícil e que os professores não utilizavam estratégias adequadas para eles. A Figura 2 menciona os principais achados para a categoria "Preparo para a Inclusão". 
Desafios Percebidos por Alunos Surdos no Ensino da Disciplina de Contabilidade Introdutória nos Cursos de Ciências Contábeis e Administração

\begin{tabular}{|c|c|c|}
\hline Categoria & Objetivo & Achados \\
\hline $\begin{array}{c}\text { Preparo para } \\
\text { a inclusão. }\end{array}$ & $\begin{array}{c}\text { Identificar o } \\
\text { preparo dos alunos } \\
\text { surdos } \\
\text { entrevistados com } \\
\text { relação ao } \\
\text { processo de } \\
\text { ensino- } \\
\text { aprendizagem de } \\
\text { Contabilidade } \\
\text { Introdutória }\end{array}$ & $\begin{array}{l}\text { [1] tiveram um início muito difícil; } \\
\text { [2] faltaram estratégias adequadas por parte dos } \\
\text { professores; } \\
\text { [3] o conhecimento dos alunos surdos se mostrou } \\
\text { defasado em relação aos ouvintes; } \\
\text { [4] dificuldade geral com teoria e interpretação de } \\
\text { textos; } \\
\text { [5] quatro alunos relataram ter experiência de } \\
\text { trabalho na área, duas fazem o Curso Superior de } \\
\text { Contabilidade, uma o Superior de Administração e } \\
\text { uma o Técnico de Administracão. }\end{array}$ \\
\hline
\end{tabular}

Figura 2 - Principais achados para a categoria "Preparo para a Inclusão"

Fonte: Elaborado pelos autores.

Na percepção dos alunos, eles chegam com um conhecimento defasado em relação aos ouvintes, necessitando de uma atenção maior para conseguirem acompanhar a turma. Nesse sentido, A8 mencionou: "muita coisa eu aprendi depois que comecei o Curso de Administração [...], meu conhecimento (anterior) não ajudou muita coisa, não". Entretanto, A3 mencionou que não é que tenha sido ruim, é que as disciplinas do Curso de Contabilidade são muito diferentes do que ele estudava anteriormente.

A dificuldade com a teoria e a interpretação dos textos, relatado por todos, se justifica com a grande diferença entre a língua portuguesa e a Libras. Essa informação vem ao encontro do que foi exposto por Daroque e Padilha (2015), quando afirmaram que os surdos que estão no ensino superior, nesse início do século XXI, trazem as marcas de abordagens clínicas e práticas pedagógicas, utilizadas durante o seu Ensino Fundamental (final do século passado), que buscavam a cura da surdez, na qual o Oralismo e a Comunicação Total dominavam e o surdo não conseguia desenvolver bem a leitura e a escrita, carregando esse descompasso até a universidade.

A escolha do curso se deu por: [1] já trabalhar em atividades que envolvia conhecimentos do curso; [2] possibilidade de trabalho na área e ajuda no cotidiano do aluno; [3] por achar que envolveria mais matemática, matéria de maior familiaridade do discente; [3] sugestão de familiares ou amigos.

\subsubsection{Categoria Processo de Ensino e Aprendizagem}

Nessa categoria, as perguntas investigam práticas pedagógicas, recursos instrucionais e tecnológicos, adaptações, experiências entre outros relacionados com o processo de ensino-aprendizagem de Contabilidade Introdutória. A Figura 3 ilustra os principais achados para a categoria "Processo de Ensino e Aprendizagem". 


\begin{tabular}{|c|c|c|}
\hline Categoria & Objetivo & Achados \\
\hline $\begin{array}{l}\text { Processo de } \\
\text { Ensino e } \\
\text { Aprendizagem }\end{array}$ & $\begin{array}{l}\text { Investigar práticas } \\
\text { pedagógicas, } \\
\text { recursos } \\
\text { instrucionais e } \\
\text { tecnológicos, } \\
\text { adaptações, } \\
\text { experiências } \\
\text { entre outros } \\
\text { relacionados com } \\
\text { o processo de } \\
\text { ensino- } \\
\text { aprendizagem de } \\
\text { Contabilidade } \\
\text { Introdutória. }\end{array}$ & $\begin{array}{l}\text { [1] as estratégias mais utilizadas são a aula expositiva } \\
\text { dialogada, seguida da resolução de exercícios } \\
\text { práticos; } \\
\text { [2] os recursos variaram entre os professores: quadro, } \\
\text { livro e atividades escritas; equipamento multimídia, } \\
\text { vídeos, internet e até o moodle no ensino presencial; } \\
\text { [3] os alunos surdos defenderam que aprendem de } \\
\text { forma diferente do ouvinte e pelo canal visual, } \\
\text { revelando a inevitabilidade de adaptações; } \\
\text { [4] os alunos não perceberam nenhuma adaptação } \\
\text { nas aulas e relataram uma resistência em mudar } \\
\text { práticas já estabelecidas e uma falta de } \\
\text { sensibilidade com as questões da surdez; e } \\
\text { [5] mesmo com todos os obstáculos, a maior parte } \\
\text { dos alunos se sente motivada. }\end{array}$ \\
\hline
\end{tabular}

Figura 3 - Principais achados para a categoria "Processo de Ensino e Aprendizagem" Fonte: Elaborado pelos autores.

A averiguação das estratégias mais utilizadas reafirmou os achados de Mazzioni (2013), variando entre professores, uns fazendo uso dos meios didáticos mais tradicionais e outros recorrendo a ferramentas de ensino e aprendizagem mais modernas.

Os relatos mostraram que a motivação está relacionada à compreensão do que é ensinado, ao gosto pela disciplina (o que só acontece se eles conseguirem compreender o conteúdo transmitido), e a um estímulo do professor ou um estímulo próprio, trazendo à tona a importância da checagem se o discente está assimilando o conhecimento transmitido e a relevância do professor como motivador e mediador do processo de ensino e aprendizagem.

Parte dos alunos veem a experiência da inclusão de alunos surdos no ensino regular de contabilidade como satisfatória, a outra parte, como precária e com a presença de resistência por parte do professor em relação às adaptações necessárias nas metodologias e práticas de ensino, indicando a necessidade de um trabalho no sentido de desmanchar essa barreira atitudinal e de melhorar alguns procedimentos de inclusão.

\subsubsection{Categoria Apoio à Inclusão}

Nessa Categoria de Apoio à inclusão foi verificado que as instituições públicas e a comunitária possuem um setor de apoio à inclusão do PAEE, no qual os alunos recebem assistência estudantil e pedagógica. A Figura 4 detalha os principais achados para a categoria "Apoio à Inclusão". 
Desafios Percebidos por Alunos Surdos no Ensino da Disciplina de Contabilidade Introdutória nos Cursos de Ciências Contábeis e Administração

\begin{tabular}{|c|c|c|}
\hline Categoria & Objetivo & Achados \\
\hline $\begin{array}{l}\text { Apoio à } \\
\text { Inclusão }\end{array}$ & $\begin{array}{c}\text { Identifica } \\
\text { ações em } \\
\text { apoio à } \\
\text { inclusão. }\end{array}$ & $\begin{array}{l}\text { [1] as instituições públicas e a comunitária possuem um setor } \\
\text { de apoio à inclusão do PAEE que trabalha em prol da } \\
\text { inclusão, mas que não vem conseguindo sensibilizar o } \\
\text { professor; } \\
\text { [2] nas duas instituições de ensino particulares, com base nos } \\
\text { relatos dos participantes, a acessibilidade é só para } \\
\text { deficientes físicos; } \\
\text { [3] o acesso vem ocorrendo: a - nas instituições públicas, } \\
\text { pelo sistema de cotas e com a indicação da necessidade } \\
\text { de ter a prova traduzida para língua de sinais. b-nas demais } \\
\text { instituições o aluno entrou de forma convencional, } \\
\text { demonstrando que ainda não estão adaptadas à } \\
\text { legislação; } \\
\text { [4] houve relato de relutância, por parte da instituição, em } \\
\text { ofertar o intérprete de Libras, e a falta dele em algumas } \\
\text { aulas; e } \\
\text { [5] a receptividade vem ocorrendo com os professores } \\
\text { demonstrando surpresa, e alguns com interesse em ajudar, } \\
\text { mas que com o passar do tempo poucos mudam a sua } \\
\text { postura em sala de aula. }\end{array}$ \\
\hline
\end{tabular}

Figura 4 - Principais achados para a categoria "Apoio à Inclusão"

Fonte: Elaborado pelos autores.

Observou-se a necessidade de a instituição propiciar uma interação entre professor e intérprete, visando uma melhora no processo de ensino e aprendizagem e de informar ao professor onde (setor da instituição) ele pode obter orientações básicas de como atuar com o seu aluno surdo.

As universidades particulares com participantes na pesquisa se mostraram relutantes na oferta de intérpretes. Houve relatos de falta de intérpretes, indicando que as instituições precisam se organizar de modo a prover a mediação entre o aluno surdo e o meio, imprescindível à aprendizagem. E também combater o preconceito ainda presente e alimentado pela falta de conhecimento. Al mencionou que no início, quando ainda não tinha intérprete, se sentia invisível aos olhos dos professores.

\subsubsection{Categoria Interação}

A avaliação da interação pelo aluno surdo é importante, mas pode ser equivocada, principalmente para os filhos de pais ouvintes que não desenvolveram uma comunicação na sua língua materna em seu convívio familiar ou social. Eles podem não ter a uma noção aproximada de até onde essa interação pode chegar, o nível de profundidade das conversas, e assim, acharem que os cumprimentos e diálogos superficiais são uma interação a contento. Constata-se que a comunicação entre o aluno surdo e alguém, que não domina a língua de sinais, seja ele professor ou aluno ouvinte, embora em alguns relatos se apresente como boa, se mostra ainda fraca ou difícil, assim como foi indicado por Lacerda (2006) e Daroque e Padilha (2015), contudo, se percebe uma pequena evolução, com passar dos anos e um insipiente, porém, crescente interesse pela Libras. A interação entre professor e intérprete se mostra respeitosa e profissional e entre aluno surdo e intérprete, muitas vezes ultrapassando os limites da sala de aula, devido à muitas vezes esse profissional 
ser uma das poucas pessoas, do convívio do discente surdo, com fluência em Libras. A melhora nesse quesito só é possível com uma maior divulgação e ensino da língua brasileira de sinais. A Figura 5 destaca os principais achados para a categoria "Interação".

\begin{tabular}{|c|c|c|}
\hline Categoria & Objetivo & Achados \\
\hline Interação & $\begin{array}{c}\text { Identificar como } \\
\text { ocorre a } \\
\text { interação } 1 \text { - } \\
\text { aluno surdo } \\
\text { com professor, } 2 \\
\text { - aluno surdo } \\
\text { com intérprete } \\
\text { de Libras, 3 - } \\
\text { professor com } \\
\text { intérprete de } \\
\text { Libras e } 4 \text { - aluno } \\
\text { surdo com } \\
\text { aluno ouvinte }\end{array}$ & $\begin{array}{l}\text { [1] a interação aluno surdo-professor é boa para quatro } \\
\text { discentes e ruim para cinco. A4 informou que o professor } \\
\text { não conseguia explicar de uma outra forma, quando ela } \\
\text { não entendia da primeira vez. A5 comenta que o professor } \\
\text { se dirigia à intérprete e pedia para que essa falasse para a } \\
\text { discente, e a intérprete explicava que ele tinha que mostrar } \\
\text { diretamente para a aluna, e complementa: "[...] a } \\
\text { sensação que o professor me dava é que não tinha } \\
\text { paciência comigo, só me apontava rapidinho assim, já } \\
\text { fugia [...] de perto de mim. Então foi bem difícil [...], eu } \\
\text { reclamei bastante, chorei muito, também". A9 revelou que } \\
\text { a partir do momento em que a instituição ofertou a } \\
\text { intérprete, os professores "largaram de mão" passando até } \\
\text { a ignorá-la; } \\
\text { [2] a interação aluno- intérprete de Libras é quase sempre } \\
\text { boa ou ótima, apenas A5 registrou problemas com alguns } \\
\text { intérpretes devido a serem pouco fluentes, faltosos, ficarem } \\
\text { em posição que atrapalhavam a sua visibilidade ou } \\
\text { ficarem usando o celular durante o trabalho de } \\
\text { interpretação, na sala de aula; } \\
\text { [3] a interação professor-intérprete também se mostrou } \\
\text { boa para a maioria, tendo apenas a observação de A5 } \\
\text { para que os professores falem compassadamente, para } \\
\text { que o intérprete consiga interpretar o conteúdo em Libras; } \\
\text { e } \\
\text { [4] a comunicação entre aluno surdo-aluno ouvinte, na } \\
\text { maior parte dos casos, só ocorre quando da presença do } \\
\text { intérprete, caso contrário se mostra superficial, se } \\
\text { resumindo a cumprimentos, mas que melhora muito } \\
\text { quando os colegas aprendem um pouco de Libras. A6 } \\
\text { aduz que uns interagem mais que outros, que depende de } \\
\text { cada pessoa. Para A7 a falta de conhecimento da surdez, } \\
\text { a diferença de idade e de objetivos dificultou a interação } \\
\text { no caso dela. }\end{array}$ \\
\hline
\end{tabular}

Figura 5 - Principais achados para a categoria "Interação"

Fonte: Elaborado pelos autores.

Com base nos relatos a presença da barreira atitudinal enfatiza a barreira da comunicação, presentes no processo. As atitudes e posturas distanciam ou aproximam alunos de professores, surdos de ouvintes. Facilitam ou dificultam a interação entre eles. Como em outras pesquisas, Lacerda (2006), Aspilicueta e Cruz (2015), Sales e Lacerda (2015), Daroque e Padilha (2015), foi confirmado que só a presença do intérprete em sala não é suficiente para que ocorra a inclusão da pessoa surda no ensino regular, sendo necessários vários outros aspectos. 
Desafios Percebidos por Alunos Surdos no Ensino da Disciplina de Contabilidade Introdutória nos Cursos de Ciências Contábeis e Administração

\subsubsection{Categoria Aspectos Facilitadores}

A maior parte dos aspectos facilitadores relatados pelos surdos estão relacionados ao seu contexto histórico (conhecimento sobre a especificidade da surdez e que ela gera de necessidade ao aluno surdo), social (melhoria na interação entre alunos surdos e ouvintes, e entre aluno surdo e professor) e cultural (necessidade de intérprete) ou com boas práticas de sala de aula (organização do quadro, assunto bem explicado). A Figura 6 faz menção aos principais achados para a categoria "Aspectos Facilitadores".

\begin{tabular}{|c|c|l|c|}
\hline Categoria & Objetivo & \multicolumn{1}{c|}{ Achados } \\
\hline & & [1] a oferta de intérprete, como essencial e irremediável; \\
[2] a utilização de mais estratégias e recursos visuais nas \\
aulas, de forma a tornar mais interessante e atrativo ao aluno \\
surdo, que não possui lembrança auditiva, mas tem a sua \\
memória visual bem treinada e desenvolvida;
\end{tabular}

Figura 6 - Principais achados para a categoria "Aspectos Facilitadores"

Fonte: Elaborado pelos autores.

\subsubsection{Categoria Aspectos Dificultadores}

Aqui também a teoria de fundo dessa pesquisa mostra a sua importância no processo de ensino e aprendizagem de Contabilidade para surdos. Os aspectos relatados nessa categoria refletem a não observação do contexto histórico, social e cultural e a não utilização de boas práticas de sala de aula, sobre um dos aspectos A5 discorre: 
[...] eu prefiro quando o professor faz [...] o começo, meio e fim. [...] o professor começa, explica uma coisa aqui, no quadro, daqui a pouco ele já pula pra outra lá na ponta, daqui a pouco volta pro meio, daqui a pouco volta pro início de novo. Fica aquele emaranhado de informações assim, no quadro, sabe. E tu não consegue ter o acompanhamento lógico.

A respeito da dificuldade do aluno surdo com relação a conteúdos mais teóricos e mais contextualizados, Daroque e Padilha (2015) expõem que a dificuldade com a segunda língua (o Português) não permite que os surdos realizem, de forma satisfatória, as atividades de leitura e escrita dos textos acadêmicos, exercícios e avaliações, como também interpretar os textos de livros didáticos, tendo embaraços em entender os conceitos, o vocabulário e os significados. Complementando o exposto, a Libras era considerada ágrafa até bem pouco tempo, tendo nos anos 70 o primeiro movimento para grafar as línguas de sinais em Copenhague, na Dinamarca, chegando ao Brasil em 1996 (DALLAN e MASCIA, 2010). Como os estudos nesse campo ainda são recentes, os surdos não têm acesso às informações escritas se não se deslocarem para outra língua. Aprender e aumentar o seu vocabulário, desenvolver a leitura e a escrita do português pode não ser algo prazeroso para o surdo, mas é necessário, pois no dia a dia do seu estudo ou trabalho, o mais provável é que as informações que vão chegar até ele e as que terá que produzir sejam na língua majoritária. A Figura 7 destaca os principais achados para a categoria "Aspectos Dificultadores".

\begin{tabular}{|c|c|c|}
\hline Categoria & Objetivo & Achados \\
\hline $\begin{array}{c}\text { Aspectos } \\
\text { Dificultadores }\end{array}$ & $\begin{array}{l}\text { Identificar } \\
\text { aspectos que } \\
\text { podem } \\
\text { dificultar o } \\
\text { processo, na } \\
\text { visão dos } \\
\text { alunos surdos }\end{array}$ & $\begin{array}{l}\text { [1] a diferença linguística; } \\
\text { [2] a falta de sinais que represente os termos técnicos; } \\
\text { [3] a falta de familiaridade com muitos conceitos } \\
\text { necessários e exigidos no curso; } \\
\text { [4] a dificuldade com a interpretação de contextos e de } \\
\text { dados, repercutindo na aplicação deles nas práticas do } \\
\text { curso; } \\
\text { [5] a apresentação de conteúdos mais teóricos e mais } \\
\text { contextualizados de forma rápida, pois o surdo tem mais } \\
\text { dificuldade nesse contexto devido a diferença linguística; } \\
\text { [6] quando o professor não explica alguns conceitos, } \\
\text { pensando que o aluno já sabe; } \\
\text { [7] quando o docente fala muito, prevalecendo o canal } \\
\text { auditivo nas aulas ou escreve e explica ao mesmo tempo } \\
\text { ou fala de costas ou apaga o quadro enquanto está } \\
\text { explicando e a intérprete traduzindo; } \\
\text { [8] a utilização de vídeos sem legenda ou janela com } \\
\text { intérprete de Libras; } \\
\text { [9] a desorganização da escrita no quadro, a permuta de } \\
\text { informações e ajuda mútua; } \\
\text { [10] trabalhar mais os conceitos dentro dos contextos; e } \\
\text { [11] em alguns casos, um atendimento individual faz } \\
\text { muita diferença no aprendizado do surdo }\end{array}$ \\
\hline
\end{tabular}

Figura 7 - Principais achados para a categoria "Aspectos Dificultadores" Fonte: Elaborado pelos autores. 
Desafios Percebidos por Alunos Surdos no Ensino da Disciplina de Contabilidade Introdutória nos Cursos de Ciências Contábeis e Administração

Quando os surdos não assimilam o que está sendo exposto em sala ou sentem que não são compreendidos, não são aceitos pelo professor ou pelos colegas, eles ficam ansiosos, nervosos e desmotivados afetando todo processo, pois cria uma barreira para o ensino, não sentem ânimo em aprender e não apresentam bom desempenho na avaliação.

\subsubsection{Categoria Sugestões para Melhorar o Ensino de Contabilidade Introdutória}

Todas as melhorias sugeridas estão relacionadas com a mediação ou com as ferramentas do processo de ensino e aprendizagem. A Figura 8 destaca os principais achados para a categoria "Sugestões para Melhorar o Ensino da Contabilidade Introdutória".

\begin{tabular}{|c|c|c|}
\hline Categoria & Objetivo & Achados \\
\hline $\begin{array}{l}\text { Sugestões } \\
\text { para } \\
\text { Melhorar o } \\
\text { Ensino da } \\
\text { Contabilida } \\
\text { de } \\
\text { Introdutória }\end{array}$ & $\begin{array}{c}\text { Identificar } \\
\text { as } \\
\text { sugestões } \\
\text { dos alunos } \\
\text { surdos para } \\
\text { melhorar o } \\
\text { ensino de } \\
\text { Contabilida } \\
\text { de } \\
\text { Introdutória }\end{array}$ & $\begin{array}{l}\text { [1] O debate, a explicação e a divulgação de como o aluno } \\
\text { surdo aprende e da cultura surda, propiciando esse } \\
\text { conhecimento ao professor; } \\
\text { [2] a preparação e sensibilização do docente para trabalhar } \\
\text { com o aluno surdo em sala; } \\
\text { [3] um trabalho prévio e em conjunto do educador com o } \\
\text { intérprete; } \\
\text { [4] oferta da disciplina de Libras como obrigatória no curso, } \\
\text { como uma forma de fomentar uma melhora na interação } \\
\text { aluno surdo-aluno ouvinte; } \\
\text { [5] fornecer, também para o intérprete, material escrito, } \\
\text { apostilas e avaliações para que ele possa ajudar na tradução } \\
\text { dos enunciados das questões; } \\
\text { [6] adaptações de atividades e de avaliações, como } \\
\text { enunciados mais enxutos e cobrança de menos questões } \\
\text { discursivas e mais objetivas; } \\
\text { [7] reciclagens contínuas para o professor se atualizar às } \\
\text { mudanças como a nova realidade da inclusão. A6 fez uma } \\
\text { sugestão bem específica e interessante; } \\
\text { [8] o uso de cores diferentes, setas e números para organizar } \\
\text { os lançamentos, saldos e transferências; } \\
\text { [9] capacitação dos professores na arte de ensinar, sugerido } \\
\text { por A9, que possui formação pedagógica e menciona que } \\
\text { trabalhar com contabilidade ou ser empresário é uma coisa, } \\
\text { passar conhecimento é outra, se referindo à necessidade de } \\
\text { conhecimentos em didática para o exercício do magistério; } \\
\text { [10] em disciplinas mais complexas é importante que os } \\
\text { intérpretes trabalhem em dupla, se alterando em espaços de } \\
\text { tempo, durante a aula. }\end{array}$ \\
\hline
\end{tabular}

Figura 8 - Principais achados para a categoria "Sugestões para Melhorar o Ensino da Contabilidade Introdutória"

Fonte: Elaborado pelos autores

\subsubsection{Categoria Percepção sobre o Papel do Professor, do Intérprete e do Aluno}

Nessa categoria, verifica-se, em determinada situação, a atribuição do outro ultrapassando o seu próprio papel, como quando o aluno entende que o intérprete tem que estudar o conteúdo do mesmo modo que ele, ou quando o professor pede para o intérprete explicar para o aluno determinado conteúdo 
que não é incumbência dele. A esse respeito, Pereira (2013) discorre sobre a importância de: [1] uma definição da função do intérprete no processo de ensino e aprendizagem e [2] o aluno surdo ter mais autonomia, por não ter um intérprete disponível fora do contexto escolar. Desta forma, é importante a consciência do seu papel e do papel do outro no processo. A Figura 9 elenca os principais achados para a categoria "Papel do Professor, do Intérprete e do Aluno".

\begin{tabular}{|c|c|c|}
\hline Categoria & Objetivo & Achados \\
\hline $\begin{array}{l}\text { Papel do } \\
\text { Professor, } \\
\text { do } \\
\text { Intérprete e } \\
\text { do Aluno }\end{array}$ & $\begin{array}{c}\text { Verificar a } \\
\text { consciência } \\
\text { sobre a } \\
\text { função dos } \\
\text { três } \\
\text { principais } \\
\text { sujeitos no } \\
\text { processo de } \\
\text { ensino- } \\
\text { aprendizag } \\
\text { em de } \\
\text { Contabilida } \\
\text { de } \\
\text { Introdutória } \\
\text { na } \\
\text { percepção } \\
\text { do aluno } \\
\text { surdo. }\end{array}$ & $\begin{array}{l}\text { [1] cabe ao professor: a) ter responsabilidade em observar o } \\
\text { nível do seu aluno orientando e o seu desenvolvimento aos } \\
\text { poucos; b) conhecer o seu aluno e fazer as adaptações } \\
\text { necessárias para atendê-lo; c) explicar o conteúdo, } \\
\text { detalhando bem os conceitos e fornecendo uma base de } \\
\text { conhecimento ao aluno; d) incentivar o aluno despertando o } \\
\text { interesse em aprender; e) se preparar com estratégias } \\
\text { compatíveis e aulas interessantes; f) cobrar o desempenho } \\
\text { dos alunos; g) verificar se o aluno esta assimilando o conteúdo } \\
\text { transmitido; h) ensinar, passando o conhecimento da melhor } \\
\text { forma possível. } \\
\text { [2] cabe ao intérprete: a) mediar a comunicação do surdo } \\
\text { com o meio, traduzindo e interpretando o português para } \\
\text { Libras e fazendo o caminho inverso; b) acompanhar o aluno } \\
\text { surdo, possibilitando a interação desse com as outras pessoas; } \\
\text { c) esclarecer conceitos que o estudante surdo não conhece; } \\
\text { d) se certificar que o aluno está entendendo, } \\
\text { compreendendo os termos; e) auxiliar o surdo na } \\
\text { compreensão do que é transmitido pelo professor, A3 } \\
\text { defende que sem o intérprete ele não aprenderia nada; f) ser } \\
\text { presente, pontual e ético; e g) ter uma maior aprendizagem } \\
\text { da disciplina, como se ele tivesse que estudar, como o aluno, } \\
\text { o conteúdo dado. } \\
\text { [3] cabe ao aluno: a) se esforçar em aprender; b) acreditar no } \\
\text { seu próprio potencial; c) estar sempre atento ao que é } \\
\text { transmitido e praticar muito; d) mostrar que é tão capaz } \\
\text { quanto os alunos ouvintes; e e) ter responsabilidade e não } \\
\text { deixar seus comnromissos nara denois }\end{array}$ \\
\hline
\end{tabular}

Figura 9 - Principais achados para a categoria "Papel do Professor, do Intérprete e do Aluno" Fonte: Elaborado pelos autores.

Os achados nessa categoria identificam o papel do professor como mediador, orientando o aluno no estudo da disciplina Contabilidade Introdutória, apresentando o aluno às terminologias específicas e possibilitando ao discente o desenvolvimento de um entendimento conceitual, a compreensão das estruturas das demonstrações financeiras e a realização de procedimentos (registro) de forma intencional e fundamentados. Essa visão está de acordo com Lantolf e Poehner (2014). Para eles, a interação entre o professor e o aluno é um exemplo da zona de desenvolvimento proximal, abordada por Vygotsky, que consiste na mediação a serviço do crescimento mental e emocional.

\subsubsection{Sobre a História e a Cultura do Aluno}

Considerando que o conhecimento humano é adquirido a partir das experiências vivenciadas pela pessoa, se torna imprescindível o estudo da história 
Desafios Percebidos por Alunos Surdos no Ensino da Disciplina de Contabilidade Introdutória nos Cursos de Ciências Contábeis e Administração

de vida e da cultura em que o aluno está imerso para conhecê-lo, e assim estudar formas de trabalhar com ele. Informações como, se o aluno só utiliza a Libras para se comunicar, se é oralizado, se domina o português escrito, se faz alguma leitura labial fazem diferença para a escolha de estratégias a serem utilizadas nas aulas. Detalhes de como se comunicam com a família e como foi o seu ensino anterior possibilita fazer um diagnóstico mais aproximado do seu conhecimento de mundo e conhecimento escolar e consequentemente já verificar a possível necessidade de um nivelamento com os alunos ouvintes ou mesmo um atendimento individual ou especializado.

Os alunos surdos entrevistados para essa pesquisa revelaram que ou nasceram surdos (cinco deles), ou perderam a audição entre 0 e 3 anos de idade (os demais), ainda na primeira infância, faixa etária marcada por intenso processo de desenvolvimento. As causas estão relacionadas à genética; doenças como rubéola ou meningite, adquiridas pela mãe, durante a gestação, ou por eles mesmos ainda muito pequenos; reação à medicação muito forte. A9 diz não ter conhecimento da causa de sua surdez. Os níveis de surdez entre eles variam de severo a profundo.

Com relação à comunicação que eles têm com a família, revelaram que a maioria dos familiares não sabem Libras, prevalecendo um conjunto do uso da leitura labial, gestos, e oralização, o que faz refletir que essa comunicação deve se repetir com os demais ouvintes com quem o surdo tem contato e o quanto isso o prejudica no seu conhecimento de mundo, devido a se restringir em poucas trocas de informações, ou a um diálogo resumido e, muitas vezes, superficial.

A percepção do surdo a respeito do seu ensino anterior mostra uma possível causa da defasagem escolar comentada em alguns relatos, dois avaliaram como bom, dois como mediano e os demais como ruim. A2 comenta que não entendia nada, estava ali por estar, e só quando veio para a capital do estado em que mora, é que realmente aprendeu alguma coisa e descobriu que havia outras pessoas surdas como ela. A esse respeito, Daroque e Padilha (2015) defendem que um desenvolvimento insuficiente de uma língua que permita a reflexão (no caso a Libras) na Educação Básica, ocasiona a falta de conhecimentos prévios e necessários ao Ensino Superior.

Com relação ao tipo da educação escolar anterior, parte dos alunos tiveram toda ela no ensino público regular, outra parcela teve o fundamental no ensino particular regular e o médio na escola pública regular. Dois alunos passaram por escolas especiais no ensino fundamental, mas parece não ter feito muita diferença e uma aluna teve todo o seu ensino anterior na escola particular regular. Cinco estudantes afirmaram ser oralizados, três deles disseram utilizar muito pouco a linguagem oral e uma discente não fazer uso desse recurso. Todos os alunos são usuários de Libras e, na percepção deles a Linguagem de sinais é como a língua portuguesa para o ouvinte, é a primeira língua do surdo, permitindo a ele se comunicar, contextualizar, se desenvolver. Nesse sentido, A3 se expressa:

[...] Libras me deixa em situação de igualdade com os alunos ouvintes. [...] é necessário que tenham surdos que saibam Libras e eles possam se comunicar, [...] é importante a inclusão do surdo para que ele possa estar se estimulando e ocupando diversos lugares. Professores e diversas áreas profissionais estarem estimulando e estarem aprendendo. 
Fazendo uma auto avaliação sobre o domínio da língua portuguesa escrita, três alunos acham que não tem uma boa compreensão do português, os demais consideram escrever bem. Porém fica limitada uma avaliação melhor a esse respeito, visto que para isso não basta apenas saber o ponto de vista do aluno. Sobre o uso de aparelho de amplificação sonora, cinco alunos não conseguiram se adaptar e quatro deles utilizam algum tipo de aparelho auditivo que os auxiliam em algum momento.

Assim, foram estudadas algumas questões da história de vida e da cultura dos alunos surdos que podem influenciar no seu desenvolvimento educacional. Os pontos tratados nesta categoria podem ser considerados ao ser feito um diagnóstico do conhecimento de mundo e escolar do aluno surdo, e podem colaborar no planejamento das aulas quando se tem um discente com essa especificidade. Não devendo se ater somente a eles, procurando outros que possam ajudar a identificar dificuldades futuras e melhorar o processo de ensino e aprendizagem de Contabilidade Introdutória ao aluno surdo.

\section{CONCLUSÕES: IMPLICAÇÕES, CONTRIBUIÇÕES, LIMITAÇÕES DA PESQUISA E RECOMENDAÇŌES}

Com início nos anos 90, as políticas educacionais de inclusão escolar proporcionaram a alunos, público alvo da educação especial, dentre eles os surdos, adentrarem no ensino técnico profissionalizante e superior. Os censos do MEC sobre a Educação Superior mostraram um grande crescimento nas matrículas de alunos PAEE com 5.078 em 2003; 11.999 em 2005; 20.530 em 2009 e 37.986 em 2015 (Ansay, 2010; MEC/INEP, 2016).

A legislação resguarda o direito à educação das pessoas surdas e estabelece diretrizes de forma geral, não sendo possível ser diferente porque cada caso é único e, embora a inclusão já seja fomentada ao redor do mundo, já tem algum tempo, o modelo atual, em que o aluno surdo é inserido no ensino regular, é recente. As experiências com a inclusão nesse formato estão sendo vivenciadas efetivamente nesse início de século, sendo tudo muito novo ainda. As vivências devem ser compartilhadas para um processo de aprendizagem que possibilite a reprodução e aperfeiçoamento das que tiveram êxito e o descarte das mal sucedidas. Aprendendo e evoluindo mais rápido com a ajuda da socialização de conhecimentos e experiências e do trabalho em conjunto de professores e outros profissionais de apoio.

O trabalho está fundamentado na teoria histórico-cultural, nos pressupostos de Vigotsky, que considera cada sujeito como um ser de características únicas, construído por meio de suas experiências com o ambiente social ao longo de sua história e imerso em uma cultura que lhe permite, a internalização dessas vivências e a formação de parâmetros de comportamento (1991), tendo as relações mediadas, principalmente, pela a linguagem (1989) e que considera a bagagem de vida do sujeito como fundamental para o ponto de vista pedagógico na questão do ensino à pessoa surda (1997).

Dessa forma e com base nas percepções dos alunos surdos os desafios são: [1] a barreira da linguagem; [2] a falta de conhecimento e de sensibilidade em relação à surdez; [3] a resistência com relação às adaptações possíveis de estratégias de ensino, de materiais e de utilização de recursos que facilitam a

38 Revista Contabilidade Vista \& Revista, ISSN 0103-734X, Universidade Federal de Minas Gerais, Belo Horizonte, v. 30, n. 3, p. 18-45, set./dez. 2019 
Desafios Percebidos por Alunos Surdos no Ensino da Disciplina de Contabilidade Introdutória nos Cursos de Ciências Contábeis e Administração

aprendizagem para alunos surdos; [4] a defasagem do conhecimento escolar anterior; [5] a relutância por parte de algumas instituições em ofertar o intérprete; [6] aulas muito faladas, desorganização na escrita do quadro e costumes como o de falar andando pela sala, falar de costas para os alunos, escrever no quadro e explicar ao mesmo tempo ou utilizar vídeos sem legendas, dificultando a tradução por parte do intérprete e uma possível ajuda vinda de uma leitura labial ou um aparelho de amplificação sonora; [7] dificuldade na interpretação e escrita, comum ao surdo; [8] a falta de sinais para representar os termos técnicos; [9] a interação entre o aluno surdo e o professor ou aluno ouvinte, que se mostra de forma bem superficial, na maioria dos discursos, prejudicando a troca de conhecimento e experiências e [10] o comprometimento dos envolvidos no processo de ensino e aprendizagem de contabilidade.

Verificou-se a aplicação da teoria histórico-cultural, confirmando que a história da vivência escolar e social do aluno, a cultura em que ele está inserido e a interação com o meio são partes constitutivas do seu desenvolvimento educacional, construindo a sua identidade. Daniels (2016) argumenta que se os fatores históricos, sociais e culturais são considerados potencialmente formativos no nível psicológico, devem ser levados em conta no processo de formação do indivíduo.

Com base nos relatos, o entendimento é que para um ensino de contabilidade com qualidade para esse público é necessário a promoção da discussão do tema que envolve vários aspectos como: a história e a cultura surda do aluno; a cultura de práticas docentes estabelecidas ao longo do tempo; a necessidade de novas posturas do docente, frente à realidade da educação inclusiva; os recursos disponibilizados e utilizados pelos docentes no ensino de contabilidade; a conscientização do papel de cada um no processo em estudo; o preparo dos professores de nível superior e técnico; uma preocupação maior e ações voltadas para a educação anterior do aluno, a formação com que o discente vem saindo do Ensino Fundamental e Médio, dentre outros.

Assim, juntando os dados coletados nas percepções relatadas com os reunidos na plataforma teórica, para uma melhora no ensino de contabilidade, como também de outras áreas que apresentam cursos de bacharelado e técnico, nessa perspectiva da inclusão de surdos no ensino regular, sugere-se: [1] a melhora da comunicação dentro das instituições, de forma a informação fluir entre órgão de apoio à acessibilidade, a coordenação e o professor; [2] o trabalho da instituição no sentido de conscientizar, sensibilizar a comunidade acadêmica em relação à surdez e orientar o professor de como atuar com o aluno surdo, por meio dos setores especializados; [3] o procedimento de levantar um diagnóstico do aluno, logo no início do curso, com o estudo da sua história para se obter a noção do seu nível de conhecimento escolar e de mundo; [4] uma maior divulgação, com incentivo do uso, da língua de sinais entre o meio acadêmico, de forma a fomentar uma maior interação entre aluno surdoprofessor e aluno surdo-aluno ouvinte; [5] capacitação na área pedagógica e de educação especial no molde de formação continuada para o professor; [6] mais utilização do visual na transmissão de conhecimento, nas atividade e avaliações, com a utilização de tempos maiores para as provas; [7] trabalho em conjunto e prévio, dos sujeitos envolvidos no processo de ensino e aprendizagem, como planejamento de aulas e apoio individual ao aluno surdo, possibilitando troca de conhecimento; [8] o compartilhamento prévio com o intérprete do 
material utilizado na disciplina, de modo a facilitar o trabalho de interpretação; [9] constante solicitação de feedback sobre a aprendizagem do aluno surdo; [10] socialização de experiências vivenciadas; [1 1] aumento da oferta de intérpretes; [12] a oferta de curso de Português Instrumental para ajudar ao surdo desenvolver a interpretação e a escrita; e [13] criação de sinais para o contexto específico da área contábil.

O trabalho traz como contribuição profissional um alerta para uma maior preocupação com a educação inclusiva nos cursos de Contabilidade e de Administração, como também, com a formação de futuros contadores com especificidade da surdez. Como contribuição acadêmica, esse reuniu informações e trouxe sugestões visando a melhoria do processo de ensino e aprendizagem de contabilidade para alunos surdos, tendo destacado a importância do intérprete educacional, porém mostrando que o êxito da inclusão depende de muitos outros fatores. A respeito da contribuição social, o estudo fomenta discussão e reflexão sobre o fenômeno da inclusão de alunos surdos no ensino de contabilidade, buscando uma sociedade mais harmônica e trazendo uma oportunidade de expandir essa discussão para outros âmbitos da sociedade.

Registra-se como limitações desta pesquisa a não validação das transcrições pelos alunos, devido à especificidade da surdez na dificuldade de interpretação e análise de textos longos. O processo de amostragem do estudo não foi probabilístico e os Achados nessa pesquisa não podem ser generalizados, até por se tratar de percepções de indivíduos, mas é possível a sua comparabilidade com outras experiências e a transferência dos entendimentos para outros contextos.

Por fim, sugere-se que sejam realizadas mais pesquisas a respeito do tema, com outras disciplinas da área contábil, em momentos diferentes do curso, como no último período, possibilitando um diagnóstico do aprendizado do aluno ao final da formação. Em que sejam utilizadas outras abordagens metodológicas, estratégias de pesquisa e técnicas de coleta de dados. E que envolva sujeitos de outras regiões geográficas.

\section{REFERÊNCIAS}

Ansay, N. N. (2010). A inclusão de alunos surdos no ensino superior. Revista do Núcleo de Estudos e Pesquisas Interdisciplinares em Musicoterapia, v.1, p. 1141.

Antunes, A. P.; Faria, C. P.; Rodrigues, S. E.; \& Almeida, L. S. (2013). Inclusão no Ensino Superior: Percepções de professores em uma universidade portuguesa. Psicologia em Pesquisa, v. 7, n. 2, p. 140-150.

Beyer, H. O. (2005). Por que Lev Vygotski quando se propõe uma educação inclusiva? Revista Educação Especial, n. 26, p. 75-81.

Bolsanello, M. A.; \& Ross, P. R. (2017). Educação especial e avaliação de aprendizagem na escola regular. Ed. da UFPR (Universidade Federal do Paraná). Curitiba, 2005. Disponível em: 
Desafios Percebidos por Alunos Surdos no Ensino da Disciplina de Contabilidade Introdutória nos Cursos de Ciências Contábeis e Administração

$<\mathrm{http}: / /$ www.cinfop.ufpr.br/pdf/colecao_1/educ_esp_7.pdf>. Acesso em: 21 de jul. 2017.

Brasil. (2004). Decreto $n^{\circ} 5.296$ de 2 de dezembro de 2004. Regulamenta as Leis $n^{\circ}$ 10.048 , de 8 de novembro de 2000, que dá prioridade de atendimento às pessoas que especifica, e 10.098, de 19 de dezembro de 2000, que trata sobre a promoção da acessibilidade das pessoas portadoras de deficiência ou com mobilidade reduzida, e dá outras providências. 2004. Disponível em:< http://www.planalto gov.br/ccivil_03/_ato20042006/2004/decreto/d5296.htm>. Acesso em: 21 de jul. 2016.

Brasil. (2004). Ministério da Educação. Conselho Nacional de Educação. Resolução no 10 de 16 de dezembro de 2004. Institui as Diretrizes Curriculares Nacionais do Curso de Graduação em Ciências Contábeis. 2004. Disponível em: <http://portal.mec.gov.br/cne/arquivos/pdf/rces10_04.pdf>. Acesso em: 21 de jul. 2017.

Brasil. (2005). Resolução $n^{\circ} 4$ de 13 de julho de 2005. Institui as Diretrizes Curriculares Nacionais do Curso de Graduação em Administração. 2005. Disponível em: $<\mathrm{http}$ ://portal.mec.gov.br/cne/arquivos/pdf/rces004_05.pdf>. Acesso em: 21 de jul. 2017.

Brasil. (2009). Resolução $n^{\circ} 4$ de 02 de outubro de 2009. Institui Diretrizes Operacionais para o Atendimento Educacional Especializado na Educação Básica, modalidade Educação Especial. 2009. Disponível em: <http://portal.mec.gov.br/dmdocuments/rceb004_09.pdf>. Acesso em: 21 de jul. 2017.

Brasil. (2015). Lei n 13.146, de 06 de julho de 2015. Institui a Lei Brasileira de Inclusão da Pessoa com Deficiência (Estatuto da Pessoa com Deficiência). Diário Oficial da União. 2015.2 Disponível em: <http://www.planalto.gov.br/ccivil_03/_ato2015-2018/2015/lei/l13146.htm>. Acesso em: 21 de jul. 2017.

Brasil, Portal. (2012). Matrículas de pessoas com deficiência em universidades cresceram $933 \%$ em dez anos. Portal Brasil. 2012. Disponível em: <http://www.brasil.gov.br/educacao/2012/10/ensino-superior-do-brasil-tem recorde-de-matriculas-nos-ultimos-anos>. Acesso em: 20 de mar. 2017.

Capovilla, F. C. (2000). Filosofias educacionais em relação ao surdo: do oralismo à comunicação total ao bilinguismo. Revista Brasileira de Educação Especial, v. 6, n. 1, p. 99-116.

Cawthon, S. W. (2001). Teaching Strategies in Inclusive Classrooms With Deaf Students. Journal of Deaf Studies and Deaf Education, v. 6, n. 3, p. 212-225.

Coelho, C. U. F. (2007). Reflexões sobre o ensino de Contabilidade: Aspectos culturais e metodológicos. Boletim Técnico do Senac, v. 33, n. 1, p. 62-75. 
Cruz, J. I. G. \& Dias, T. R. S. (2009). Trajetória Escolar do Surdo no Ensino Superior: Condições e Possibilidades. Revista Brasileira de Educação Especial, v. 15, n. 1, p. 65-80.

Dallan, M. S. S.; \& Mascia, M. A. (2010). A escrita de Libras (SIGNWRITING): Um olhar para o desenvolvimento linguístico do aluno surdo e para a formação do professor de línguas. In: III Congresso Latino-Americano de Formação de Professores de Línguas. Universidade de Taubaté, São Paulo, Brasil.

Daniels, H. (2016). Vygotsky and pedagogy. Routledge.

Daroque, S. C. \& Padilha, A. M. L. (2015). Reflexões acerca de alunos surdos no Ensino Superior. In: Bagarollo, M. F. \& França, D. M. V. R. (Orgs.). Surdez, escola e sociedade: reflexões sobre Fonoaudiologia e Educação. Rio de Janeiro: Wak Editora.

Dorziat, A. (1999). Sugestões docentes para melhorar o ensino de surdos. Cadernos de Pesquisa, (108), 183-198.

Duarte, E. R.; Rafael, C. B. S.; Filgueiras, J. F.; Neves, C. M.; \& Ferreira, M. E. C. (2013). Estudo de caso sobre a inclusão de alunos com deficiência no Ensino Superior. Revista Brasileira de Educação Especial, v. 19, n. 2, p. 289-300.

Farias, M. R. S. (2012). Desenvolvimento científico da contabilidade: uma análise baseada na epistemologia realista da ciência. 2012 (Doctoral dissertation, Tese (Doutorado) - Curso de Ciências Contábeis, Departamento de Contabilidade e Atuária da Faculdade de Economia, Administração e Contabilidade, Universidade de São Paulo, São Paulo).

Fernandes, S. (2008). Educação Bilíngue para Surdos: o contexto brasileiro. In: I Seminário sobre Inclusão no Ensino Superior: trajetória do estudante surdo, UEL.

Fernandes, S. (2011). Educação de surdos. Curitiba: IBPEX.

Garcia, R. M. C. (2011). Política nacional de educação especial nos anos 2000: a formação de professores e a hegemonia do modelo Especializado. In: Baptista, C.R.; Caiado, K. R. M.; \& Jesus, D.M. Professores e Educação Especial: formação em foco. Porto Alegre: Mediação, p. 65-78.

Gil, A. C. (2008). Métodos e técnicas de pesquisa social. 6. ed. São Paulo. Editora Atlas.

Goldfeld, M. (2002). A criança surda: linguagem e cognição numa perspectiva sociointeracionista. 2. Ed. São Paulo. Plexus Editora.

Gonçalves, H. B. \& Festa, P. S. V. (2013). Metodologia do Professor no Ensino de Alunos Surdos. Revista Eletrônica do Curso de Pedagogia das Faculdades OPET, dezembro. 
Desafios Percebidos por Alunos Surdos no Ensino da Disciplina de Contabilidade Introdutória nos Cursos de Ciências Contábeis e Administração

Hammami, S.; Saeed, F.; Mathkour, H. \& Arafah, M. A. (2019). Continuous improvement of deaf student learning outcomes based on an adaptive learning system and an Academic Advisor Agent. Computers in Human Behavior, v. 92, p. 536-546.

Hofer, E. (2004). Ensino de Contabilidade introdutória nos cursos de Ciências Contábeis das universidades estaduais do Paraná: um estudo exploratório. Dissertação (Mestrado em Controladoria e Contabilidade Estratégica). UNIFECAP, São Paulo.

Instituto Brasileiro de Geografia e Estatística - IBGE. (2010). Censo Demográfico 2010. Características Gerais da População, Religião e Pessoas com Deficiência. Rio de Janeiro, 2012. Disponível em: <http://www.ibge.gov.br/home/presidencia/ noticias/imprensa/ppts/00000009352506122012255229285110.pdf>. Acesso em: 21 de mai. 2017.

Jambor, E.; \& Elliott, M. (2005). Self-esteem and Coping Strategies among Deaf Students. Journal of Deaf Studies and Deaf Education, v. 10, n. 1, p. 63-81.

Lacerda, C. B. F. (2006). A inclusão escolar de alunos surdos: o que dizem alunos, professores e intérpretes sobre esta experiência. Cad. Cedes, v. 26, n. 69, p. 163-184.

Lacerda, C. B. F; Albres, N. A.; \& Drago, S. L. S. (2013). Política para uma educação bilíngue $e$ inclusiva a alunos surdos no município de São Paulo. Educ. Pesqui., v. 39, n. 1, p. 65-80, jan./mar.

Lang, H. G. (2002). Higher Education for Deaf Students: Research Priorities in the New Millennium. Journal of Deaf Studies and Deaf Education, v. 7, n. 14, p. 267-280.

Lantolf, J. P.; \& Poehner, M. E. (2014). Sociocultural theory and the pedagogical imperative in education: Vygotskian práxis and the research/practice divide. Routledge.

Martins, G. A.; \& Theóphilo, C. R. (2007). Metodologia da Investigação Cientifica. São Paulo: Atlas.

Marschark, M.; Morrison, A.; Lukomski, J.; Borgna, G.; \& Convertino, C. (2013). Are deaf students visual learners? Learning and Individual Differences, v. 25, p. 156, 162.

Marschark, M; Shaver, D. M.; Nagle, K. M.; \& Newman, L. A. (2015). Predicting the academic achievement of deaf and hard-of-hearing students from individual, household, communication, and educational factors. Exceptional children, $v$. 81, n. 3, p. 350-369.

Mazzioni, S. (2013). As estratégias utilizadas no processo de ensino-aprendizagem: concepções de alunos e professores de ciências contábeis. Revista Eletrônica de Administração e Turismo-ReAT, v. 2, n. 1, p. 93-109. 
Minick, N. (1987). The development of Vygotsky's thought: An introduction In: The collected Works of LS Vygotsky. Springer, Boston, MA, p. 17-36.

Ministério da Educação e Cultura - MEC. (2006). Saberes e práticas da inclusão: desenvolvendo competências para 0 atendimento às necessidades educacionais especiais de alunos surdos, [2, ed] / coordenação geral SEESP/MEC, - $\quad$ Brasília, 2006.2 Disponível em: <http://portal.mec.gov.br/seesp/arquivos/pdf /const_escolasinclusivas.pdf>. Acesso em: 27 de jul. 2017.

Ministério da Educação e Cultura - MEC. (2010). Resumo Técnico Censo da Educação Superior de 2009. Brasília, 2010. Disponível em: <http://download.inep.

gov.br/download/superior/censo/2009/resumo_tecnico_2009.pdf>.

Acesso em: 27 de jul. 2017.

Ministério da Educação e Cultura - MEC. (2016). Censo da Educação Superior 2015. Brasília, 2016. Disponível em: <http://download.inep.gov.br/educacao_ superior/censo_superior/apresentacao/2015/Apresentacao_Censo_Superior_ 2015.pdf>. Acesso em: 27 de jul. 2017.

Ministério da Educação e Cultura - MEC. (2019). Resumo Técnico Censo da Educação Superior de 2017. Brasília, 2019. Disponível em: <http://download.inep.gov.br/educacao_superior/censo_superior/resumo_† ecnico/resumo_tecnico_censo_da_educacao_superior_2017.pdf>. Acesso em: 27 de jan. 2020.

Moriña, A.; Cortés-Vega, M. D.; \& Molina, V. M. (2015). What if we could imagine the ideal faculty? Proposals for improvement by university students with disabilities. Teaching and Teacher Education, v. 52, p. 91-98, 2015. Disponível em: http://www.sciencedirect.com/science/article/pii/S0742051X15300081. Acesso em: 29 de mar. 2017.

Pacheco, R. V.; \& Costas, F. A. T. (2006). O processo de inclusão de acadêmicos com necessidades educacionais especiais na Universidade Federal de Santa Maria. Revista Educação Especial, n. 27, p. 151-169.

Peleias, I. R.; Silva, G. P.; Segreti, J. B.; \& Chirotto, A. R. (2007). Evolução do ensino da contabilidade no Brasil: uma análise histórica. Revista Contabilidade \& Finanças-USP, v. 18, p. 19-32.

Pereira, O. R. (2013). Alunos surdos, Intérpretes de libras e professores: Atores em contato na universidade. Cadernos de Educação, v. 12, n. 24, p. 73-96.

Pieczkowski, T. M. Z. (2012). Inclusão no Ensino Superior: Barreiras Relatadas pelos Estudantes com Deficiência. Apresentado na IX ANPED Sul. Anais... Caxias do Sul, $2012 . \quad$ Disponível em: <http://www.ucs.br/etc/conferencias/index.php/anpedsul/ 9anpedsul/paper/viewFile/100/678>. Acesso em: 20 de mar. 2017. 
Desafios Percebidos por Alunos Surdos no Ensino da Disciplina de Contabilidade Introdutória nos Cursos de Ciências Contábeis e Administração

Poehner, M. E.; \& Infante, P. (2017). Mediated development: A Vygotskian approach to transforming second language learner abilities. TESOL Quarterly, 51.2: 332-257.

Rego, T. C. (2013). Vygotsky: uma perspectiva histórico-cultural da educação. Petropólis, RJ. Editora Vozes Limitada.

Rodrigues, A. T. (2014). Entrevista concedida ao Jornal do Comércio in: Engster, A. O futuro do técnico em contabilidade em xeque. Jornal do Comercio. Porto Alegre. Disponivel em: <http://jcrs.uol.com.br/site/noticia.php?codn=162852>. Acesso em: 20 de mar. 2017.

Sá, A. L. (1997). História Geral e das Doutrinas da Contabilidade. Editora Atlas: São Paulo.

Sales, A. C. M.; \& Lacerda, C. B. F. (2015). Reflexões sobre o papel e a prática de intérpretes de língua de sinais no ensino fundamental. In: BARAGOLLO, M. F.; FANÇA, D. M. V. R. (Org.). Surdez, Escola e Sociedade: reflexões sobre Fonoaudiologia e Educação. Rio de Janeiro: Walk Editora.

Sládek, P.; Bednárová, R.; \& Miléra, T. (2011). On some aspect of teaching hearinghandicapped students in standard courses. Procedia-Social and Behavioral Sciences, v. 12, p. 145-149.

Spencer, L. J.; Marschark, M.; Machmer, E.; Durkin, A.; Borgna, G.; \& Convertino, C. (2018). Communication skills of deaf and hard-of-hearing college students: objective measures and self-assessment. Journal of Communication Disorders, v. 75, p. 13-24.

Vermeulen, J. A.; Denessen, E.; \& Knoors, H. (2012). Mainstream teachers about including deaf or hard of hearing students. Teaching and Teacher Education, v. 28, p. 174, 181

Vygotsky, L. S. (1989). Pensamento e linguagem. São Paulo: Martins Fontes.

Vygotsky, L. S. (1991). A formação social da mente. São Paulo: Martins Fontes.

Vygotsky, L. S. (1997). Obras Escogidas Tomo V. Fundamentos de defectología. Madrid: Visor Dis.

Witt, D.; Alias, N.; Ibrahim, Z.; Shing, N. K.; \& Mohd-Rashid, S. M. (2015). Design of a learning module for the deaf in a higher education institution using padlet. Procedia - Social and Behavioral Sciences, v. 176, p. 220-226.

Zanluca, J. C.; \& Zanluca, J. D. S. (2006). História da contabilidade. Compilação: Equipe Portal de Contabilidade, 2006. Disponível em: <http://www.portalde contabilidade.com.br/tematicas/historia.htm>. Acesso em: 21 de jul de 2017. 